\title{
Temporal analysis of the weight/carapace width relationship and the condition factor in Uca mordax (Smith, 1870) (Crustacea, Decapoda, Ocypodidae) in the Igaraçu River, Parnaíba, PI, Brazil
}

\author{
Luiz Gonzaga Alves dos Santos Filho ${ }^{1 *}$ \\ Sidely Gil Alves Vieira dos Santos ${ }^{1}$ \\ João Marcos de Góes ${ }^{1}$ \\ Lissandra Corrêa Fernandes-Góes ${ }^{2}$ \\ ${ }^{1}$ Universidade Federal do Piauí, Campus Universitário Ministro Reis Velloso \\ CEP 64202-020, Parnaíba - PI, Brasil \\ ${ }^{2}$ Universidade Estadual do Piauí, Campus Universitário Professor Alexandre Alves de Oliveira \\ CEP 64202-220, Parnaíba - PI, Brasil \\ * Autor para correspondência \\ luizgonga@ufpi.edu.br
}

Submetido em 27/08/2015

Aceito para publicação em 07/12/2015

\section{Resumo}

Análise temporal da relação peso/largura de carapaça e fator de condição em $\boldsymbol{U}$ ca mordax (Smith, 1870) (Crustacea, Decapoda, Ocypodidae) no Rio Igaraçu, Parnaíba, PI, Brasil. Os caranguejos do gênero Uca Leach, 1814 são amplamente distribuídos na costa brasileira e desempenham importante papel ecológico no ecossistema estuarino na bioturbação do solo, ciclagem de nutrientes e servindo como fonte de alimento para outros organismos. Este estudo objetiva analisar a relação peso úmido/largura da carapaça e a dinâmica temporal do fator de condição do caranguejo Uca mordax (Smith, 1870). Os caranguejos foram coletados manualmente na margem do Rio Igaraçu (0253'58'S; 4146’49”W), de setembro de 2009 a junho de 2011, no período seco e chuvoso da região. Foram analisados 602 caranguejos (449 machos e 153 fêmeas). Determinou-se a largura da carapaça (LC) e o peso úmido (PU) de cada indivíduo. Os dados biométricos obtidos foram submetidos a uma regressão, por meio do software REGRANS, utilizando-se a equação do tipo potência $\left(\mathrm{y}=\mathrm{ax}^{\mathrm{b}}\right)$. A relação PU/ $\mathrm{LC}$ para os machos foi expressa pela equação $\mathrm{PU}=0,00011 \mathrm{LC}^{3,441}$, e para as fêmeas por $\mathrm{PU}=0,00018 \mathrm{LC}{ }^{3,211}$. $\mathrm{O}$ fator de condição foi determinado para cada mês de coleta, e comparado entre os sexos. As fêmeas apresentaram o grau de engorda cerca de 1,6 vezes maior que o dos machos. No período chuvoso as fêmeas apresentam um crescimento em peso do tipo isométrico, enquanto as demais relações (machos no período seco e chuvoso, e fêmeas no período seco) apresentaram crescimento alométrico positivo. Não houve diferença significativa entre o grau de engorda de machos e fêmeas.

Palavras-chave: Alometria; Chama-maré; Grau de engorda 


\section{Abstract}

Crabs of the genus $U c a$ Leach, 1814 are widely distributed along the Brazilian coast and play an important ecological role in the estuarine ecosystem in soil bioturbation, nutrient cycling and by serving as a food source for other organisms. This study analyzed the relationship of wet weight/carapace width and the temporal dynamics of the condition factor of the crab Uca mordax (Smith, 1870). The crabs were sampled manually on the bank of the Igaraçu River (02 $53^{\prime} 58^{\prime \prime} S$; 41 46 '49'W) from September 2009 to June 2011, in the dry and rainy seasons. A total of 602 crabs (449 males and 153 females) were analyzed. The carapace width (CW) and the wet weight (WW) were determined for each individual. The biometric data obtained were submitted to a regression analysis using the power equation $\left(\mathrm{y}=\mathrm{ax}^{\mathrm{b}}\right)$. The $\mathrm{CW} / \mathrm{WW}$ relationship for males was expressed by the equation $\mathrm{WW}=0.00011 \mathrm{CW}^{3,441}$, and for females by $\mathrm{WW}=0.00018 \mathrm{CW}^{3.211}$. The condition factor was determined for each month and compared between the sexes. The females showed a 1.6 higher degree of fattening than the males. In the rainy season the females showed an isometric increase in weight, while the other relationships (males during the dry and rainy seasons and females in the dry season) showed a positive allometric increase. There was no significant difference in the degree of fattening between males and females.

Key words: Allometry; Degree of fattening; Fiddler crab

\section{Introduction}

Fiddler crabs of the genus Uca Leach, 1814 are the most characteristic group of invertebrates in tropical and subtropical estuaries (BENETTI et al., 2007; MOKHLESI et al., 2010). These crabs burrow in the sediment and build complex galleries (BENETTI et al., 2007) are important consumers of detritus, bacteria, fungi, and benthic microalgae in mangroves (WEIS; WEIS, 2004), and are an important food for many predators in this ecosystem (LITULO, 2005a). Burrowing and foraging activities of fiddler crabs promote bioturbation of estuarine intertidal flats (COLPO; NEGREIROS-FRANSOZO, 2004), helping to cycle nutrients and energy (MOKHTARI et al., 2008).

Populations of fiddler crabs have attracted the interest of the scientific community. In Brazil, their population biology has been studied in the states of Ceará (BEZERRA; MATTHEWS-CASCON, 2006; 2007), São Paulo (RIEGER, 1998; COLPO; NEGREIROS-FRANSOZO, 2004; BENETTI et al., 2007; 2008; FRANSOZO et al., 2009), Rio de Janeiro (CASTIGLIONI et al., 2006), Paraná (DI BENEDETTO; MASUNARI, 2009) and Pará (SIMITH et al., 2014), their relative growth has been studied in Santa Catarina (MASUNARI; SWIECH-AYOUB, 2003), Paraná (MASUNARI; DISSENHA, 2005; MASUNARI et al., 2005), São Paulo (BENETTI; NEGREIROSFRANSOZO, 2004; CARDOSO; NEGREIROS-
FRANSOZO, 2004) and Rio de Janeiro (PRALON; NEGREIROS-FRANSOZO, 2008), and their diversity and distribution has also been studied (ARAÚJO et al., 2014).

In brachyurans, studies on relative growth have used several morphometric relationships to evaluate patterns of allometry (GÓES; FRANSOZO, 1997). The different patterns of growth appear in length as well as in weight, which are determined by their anatomical functions, and reflect physiological requirements stemming from the nature of trophic relationships and genetic factors (FONTELES-FILHO, 2011). The growth in weight is determined ontogenetically, but it can differ depending on sex, maturation phase, or locality (HARTNOLL, 1982).

The analysis of the relationship between weight and carapace width may provide important information about the biomass of a population (SANTOS, 1978). Such studies commonly use a power equation $\left(y=a x^{b}\right)$, where the value of "a" indicates the increase in weight (conditional factor), showing variations in different phases of growth, between sexes, and in populations from different localities (SANTOS, 1978). The value of "b" shows the kind of growth, which may be isometric $(b=3$, weight and carapace width grow in equal proportions), negative allometric $(b<3$, weight increases less in proportion to carapace width) and positive allometric $(b>3$, weight increases more in proportion to carapace width). 
The few studies in Brazil relating weight to carapace width in crustaceans were carried out on Callinectes danae (BRANCO; THIVES, 1991; BRANCO et al., 1992), Portunus spinimanus (SANTOS et al., 1995), Arenaeus cribrarius (AVILA; BRANCO, 1996) and Dilocarcinus pagei (PINHEIRO; TADDEI, 2005).

This study evaluated the relationships of wet weight vs. carapace width $(\mathrm{WW} / \mathrm{CW})$ in the fiddler crab Uca mordax, and the temporal dynamics of its condition factor.

\section{Material and Methods}

The crabs were sampled on the bank of the Igaraçu River (02'53'58'S; 41 $46^{\prime}$ '49'W), in the municipality of Parnaíba, Piauí State, Brazil. The samples were taken from September 2009 to June 2011, in the dry season (September, October and November) and rainy season (April, May and June). The collections were made manually by two people for $1 \mathrm{~h}$, in a random fashion, at low tide, by capturing the crabs inside and outside of their burrows. In the laboratory, the crabs were sexed and their carapace width $(\mathrm{CW})$ was measured, to the nearest $0.05 \mathrm{~mm}$, using a vernier caliper. The individual wet weight (WW) was also obtained, after defrost and drying on paper towels. Only intermolt crabs were used in the analyses.

In relation to climatic parameters, the Piauí coast is directly influenced by the Intertropical Convergence Zone (ITCZ). This provides intense and relatively regular rainfall, especially in the first six months of the year when the most rainfall occurs, and a period of drought during the second half of the year (MARCELINO et al., 2002). In the municipality of Parnaíba the average temperature ranges from $22{ }^{\circ} \mathrm{C}$ to $32{ }^{\circ} \mathrm{C}$ and the average annual rainfall is greater than 1,300 mm (CEPRO, 2013).

The biometric data were submitted to a regression analysis, based on REGRANS (PEZZUTO, 1993), using the function $y=a x^{b}$, where " $x$ " is the independent variable $(\mathrm{CW})$ and the wet weight (WW) " $\mathrm{y}$ " is the dependent variable. The statistical significance of " $b$ " was tested using Student's t-test $(\alpha=5 \%)$ (ZAR, 2010).
The power equations obtained were log-transformed $(\log \mathrm{y}=\log \mathrm{a}+\mathrm{b} \log \mathrm{x})$, which is considered the simplest method to show the data for relative growth (HARTNOLL, 1982) in a linear fashion, and allowed the parameters "a" and " $b$ " to be estimated using the least-squares regression method (PEZZUTO, 1993).

The condition factor, represented by "a" was determined for each month and sex. The values obtained were analyzed for normality using the Shapiro-Wilk test, and were compared using the Mann-Whitney test $(\alpha=5 \%)($ ZAR, 2010).

\section{Results}

A total of 602 specimens of Uca mordax were analyzed (449 males and 153 females). The $\mathrm{CW}$ ranged from 6.35 to $21.10 \mathrm{~mm}$ for the males and from 6.85 to $22.00 \mathrm{~mm}$ for the females. The males showed a mean carapace width $(17.18 \mathrm{~mm} \pm 3.66)$ and weight $(2.37 \mathrm{~g} \pm$ $1.48)$ that was significantly larger and heavier than the females $(15.05 \mathrm{~mm} \pm 3.19$ and $1.27 \mathrm{~g} \pm 0.71)(\mathrm{p}<0.05)$.

The $\mathrm{WW} / \mathrm{CW}$ relationship for the males was expressed by the equation $\mathrm{WW}=0.00011 \mathrm{CW}^{3.441}$ $\left(\mathrm{R}^{2}=0.978\right)$, and for females by $\mathrm{WW}=0.00018 \mathrm{CW}^{3.211}$ $\left(\mathrm{R}^{2}=0.969\right)$ (Figure 1), and showed a positive allometric growth in weight $(b>3)$ for both sexes $(p<0.05)$. The constant " $b$ " is compatible with the value determined for other aquatic organisms, which is between 2 and 4 (HARTNOLL, 1982). A high and positive coefficient of determination was found in all analyses $\left(\mathrm{R}^{2}>0.960\right)$.

In the rainy seasons, the females showed isometric growth (Student's t: $\mathrm{p}>0.05$ ). The other relationships (males in dry and rainy seasons and females in the dry season) showed positive allometric growth (Student's t: $\mathrm{p}<0.05$ ) (Table 1).

The values of the condition factor showed a not normal distribution $(p<0.05)$. The females showed a degree of fattening about 1.6 times higher than the males, with a similar monthly pattern in both sexes (Figure 2). The mean condition factor in females (4.17 \pm 3.42 ) showed no significant difference from that of males $(1.86 \pm 0.98)$ during the study period. 
FIGURE 1: Uca mordax (Smith, 1870). Scatter plot of points of wet weight (WW) and carapace width (CW) for males (A) and females (B) sampled in the Igaraçu River, Parnaíba, PI, Brazil.

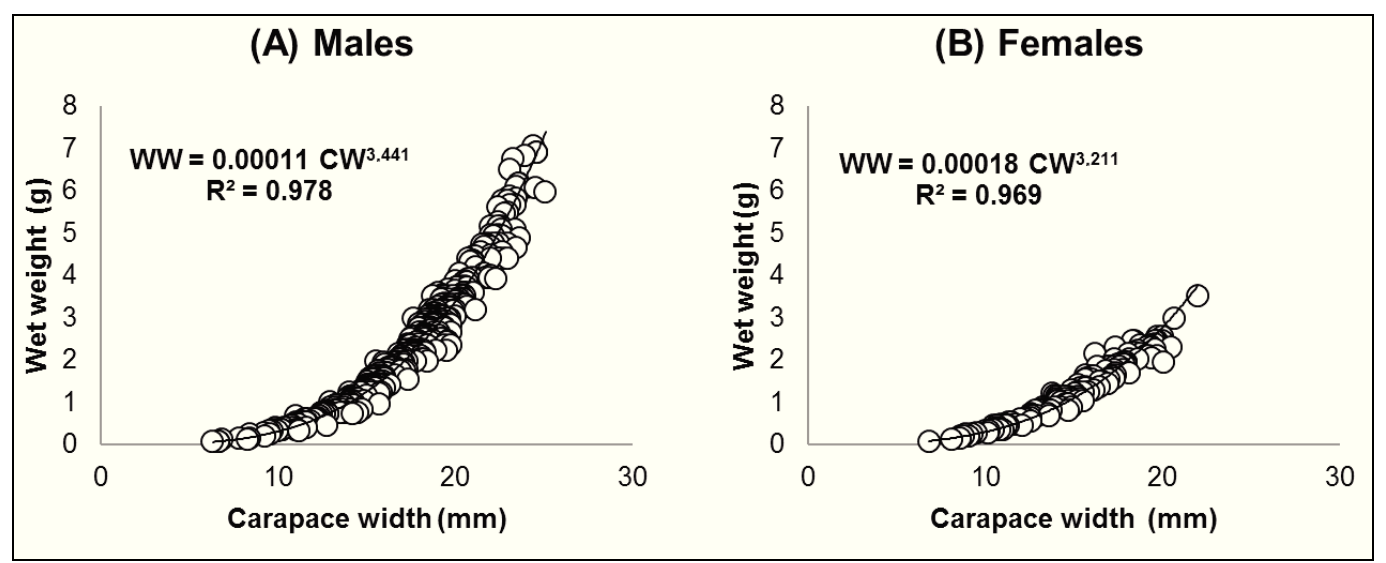

TABLE 1: Uca mordax (Smith, 1870). Result of the regressions obtained for the fiddler crab population in the Igaraçu River. Carapace width $(\mathrm{CW})$ was used as the independent variable and wet weight $(\mathrm{WW})$ as the dependent variable. Codes: F, females; M, males; DP, dry period; RP, rainy period; $T$, total; $\mathrm{R}^{2}$, coefficient of determination, $t$, value for Student's t-test; allometry, test for slope of b; 0, isometry; + positive allometry;*, significance $(\mathrm{p}<0.05)$.

\begin{tabular}{ccccccc}
\hline Sex & $\mathbf{n}$ & $\begin{array}{c}\text { Power equation } \\
\mathbf{Y}=\mathbf{a x}^{\mathbf{b}}\end{array}$ & $\begin{array}{c}\text { Linearized equation } \\
\mathbf{l n} \mathbf{y}=\mathbf{l n} \mathbf{a}+\mathbf{b} \mathbf{l n} \mathbf{x}\end{array}$ & $\mathbf{R}^{\mathbf{2}}$ & $\mathbf{t}\left(\mathbf{H}_{\mathbf{0}}: \mathbf{b}=\mathbf{3}\right)$ & Allom. \\
\hline $\mathrm{M} \mathrm{DP}$ & 234 & $\mathrm{WW}=0.00009 \mathrm{LC}^{3.505}$ & $\ln \mathrm{WW}=-9.316+3.505 \operatorname{lnCW}$ & 0.980 & $15.375^{*}$ & + \\
$\mathrm{M} \mathrm{RP}$ & 215 & $\mathrm{WW}=0.00013 \mathrm{LC}^{3.397}$ & $\ln \mathrm{WW}=-8.948+3.397 \operatorname{lnCW}$ & 0.979 & $11.887^{*}$ & + \\
$\mathrm{M} \mathrm{T}$ & 449 & $\mathrm{WW}=0.00011 \mathrm{LC}^{3.441}$ & $\ln \mathrm{WW}=-9.115+3.441 \operatorname{lnCW}$ & 0.978 & $18.132^{*}$ & + \\
$\mathrm{F} \mathrm{DP}$ & 60 & $\mathrm{WW}=0.00014 \mathrm{LC}^{3.276}$ & $\ln \mathrm{WW}=-8.874+3.276 \operatorname{lnCW}$ & 0.984 & $5.097 *$ & + \\
F RP & 93 & $\mathrm{WW}=0.00024 \mathrm{LC}^{3.119}$ & $\ln \mathrm{WW}=-8.335+3.119 \operatorname{lnCW}$ & 0.960 & 1.816 & 0 \\
F T & 153 & $\mathrm{WW}=0.00018 \mathrm{LC}^{3.211}$ & $\ln \mathrm{WW}=-8.623+3.221 \operatorname{lnCW}$ & 0.969 & $4.572 *$ & + \\
\hline
\end{tabular}

The mean condition factor did not differ significantly $(\mathrm{p}>0.05)$ between sexes in the dry or rainy season (Figure 2 ).
Also it showed no significant difference between the dry season and rainy season for either sex $(\mathrm{p}>0.05)$.

FIGURE 2: Uca mordax (Smith, 1870). Monthly values of the condition factor for each sex sampled in the Igaraçu River, Parnaíba, PI, Brazil.

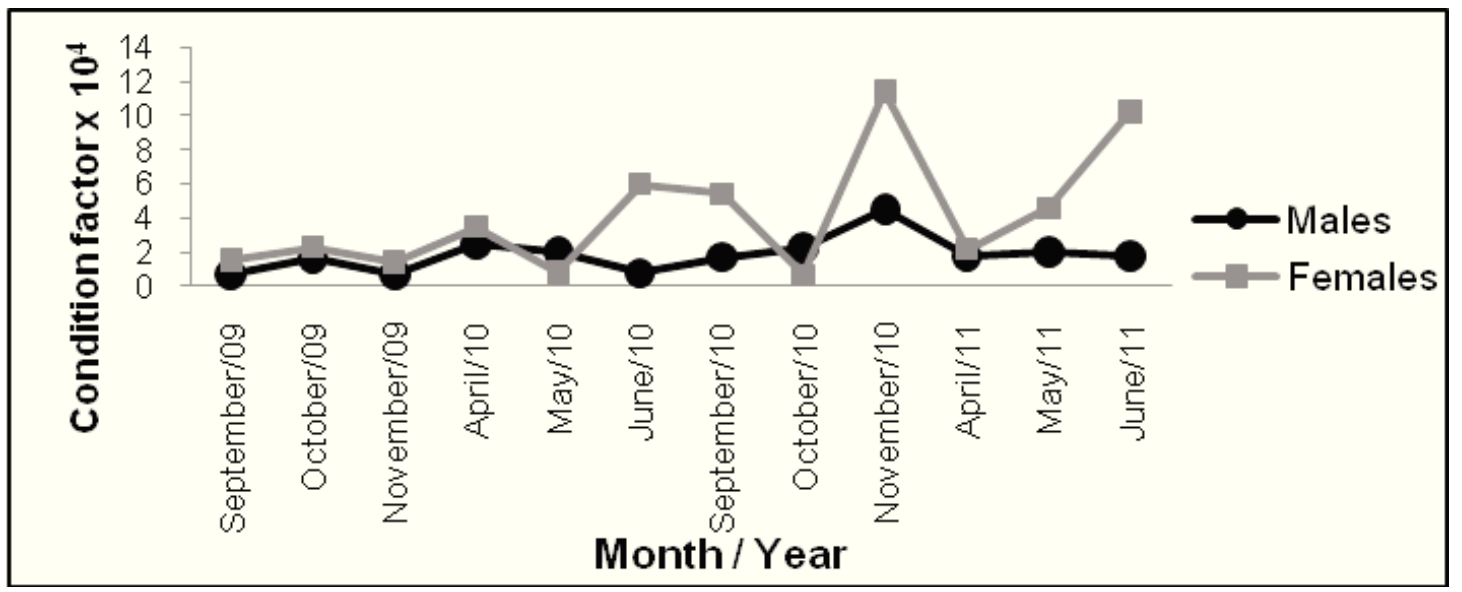




\section{Discussion}

Other studies of species of $U c a$ have also found that males grow larger than females (LITULO, 2005a; 2005b; BEZERRA; MATTHEWS-CASCON, 2006; CASTIGLIONI et al., 2006; MOKHTARI et al., 2008; DI BENEDETTO; MASUNARI, 2009). This dimorphism in the size of crabs may result from a greater investment in somatic growth by males, while females expend most of their energy for reproduction, allowing males to reach larger sizes (CHRISTY; SALMON, 1984; DÍAZ; CONDE, 1989; MANTELATTO; FRANSOZO, 1994; JOHNSON, 2003; CASTIGLIONI; NEGREIROS-FRANSOZO, 2004; COLPO; NEGREIROS-FRANSOZO, 2004; MASUNARI et al., 2005; CASTIGLIONI et al., 2006).

During the juvenile stages of these crabs, the demand for energy is directed toward the development of certain organs or structures, to reach an appropriate functional size, and in females, after the puberty molt, the energy costs for reproduction are included, and the growth per molt is reduced because of the smaller amount of available energy (COBO; FRANSOZO, 1998). The males have a large cheliped that is about 4 to 5 times bigger than the smaller one and is used in male-to-male combat and as a display for females during courtship (ROSENBERG, 2002), which increases their weight in relation to females. The bigger size of males may also result from the necessity to fertilize more than one female, because larger males have more chances to copulate (JOHNSON, 2003; LITULO, 2005a).

The isometry observed in the weight of females, in the rainy season, may be a sign of reproduction, because of the reduction in the proportion of their weight (MOKHTARI et al., 2008). The energy expenditure of females for reproduction retards their growth during the reproductive period (HARTNOLL, 1982). The weight of gonads in crustaceans changes significantly during the breeding season, which can cause a decreased growth rate in weight due to releasing gametes or recovery of the gonads (BRANCO et al., 1992). In addition, the ovigerous females can remain in their burrows throughout the incubation period and eat less food during this period, which contributes to weight reduction (BENETTI et al., 2007).
The equality in the means of the condition factor between the sexes may show that although the males reach a higher weight than females, the rate of fattening is similar in both sexes, indicating the condition factor is independent of the largest size reached by each sex. The males weigh more because they reach larger sizes than females and also due to the large cheliped, as discussed above.

The slight superiority in the degree of fattening of females, which in some months show values higher than males, may also occur due to differential feeding between the sexes. The females have an advantage because they can use both chelipeds for feeding, whereas males reserve their larger cheliped for display and combat (WEIS; WEIS, 2004; MOKHLESI et al., 2010). Branco et al. (1992) determined for Callinectes danae that the availability of food during the year influences the condition factor less than gonadal development. Thus, the feeding advantage of females may not be conclusive in causing the small difference in the degree of fattening between the sexes, and should be further studied for this genus.

In brachyuran crabs, growth and reproduction are regulated by hormones, and only somatic growth or gonadal development may occur. After that, females reach sexual maturity and their energy is expended mostly for reproduction, in contrast to males (DÍAZ; CONDE, 1989); there is also a tendency toward more energy use by females, which can be observed in the slightly higher condition factor of females.

It can be observed that the condition factor in Uca mordax expressed the "welfare" of the species in the study area, indicating that environmental resources provide optimal nutritional conditions for its sustainability. The variations observed in the condition factor and the relationship between weight and carapace width, especially for females, may be related to gonadal development, economy and energy expenditure.

\section{References}

ARAÚJO, M. L. S. C.; TENÓRIO, D. O.; CASTIGLIONI, D. S. Diversidade e distribuição dos Crustacea Brachyura dos manguezais dos rios Ariquindá e Mamucabas, litoral sul de Pernambuco, Brasil. 
Journal of Integrated Coastal Zone Management, Faro, v. 14, n. 3, p. 483-499, 2014.

AVILA, M. G.; BRANCO, J. O. Aspectos bioecológicos do siri Arenaeus cribrarius (Lamark, 1818) (Decapoda, Portunidae) na Praia da Barra da Lagoa, Florianópolis, SC, Brasil. Revista Brasileira de Zoologia, Curitiba, v. 13, n. 1, p. 165-176, 1996.

BENETTI, A. S.; NEGREIROS-FRANSOZO, M. L. Relative growth of Uca burgersi (Crustacea, Ocypodidae) from two mangroves in the southeastern Brazilian coast. Iheringia, Porto Alegre, v. 94, n. 1, p. 67-72, 2004.

BENETTI, A. S.; NEGREIROS-FRANSOZO, M. L.; COSTA, T. M. Population and reproductive biology of the crab Uca burgersi Holthuis, 1967 (Crustacea, Brachyura) in three subtropical mangrove forests. Revista de Biologia Tropical, San José, v. 55, n. 1, p. 55-70, 2007.

BENETTI, A. S.; SANTOS, D. C.; NEGREIROS-FRANSOZO, M. L.; SCELZO, M. A. Spermatozoal ultrastructure in three species of the genus Uca Leach, 1814 (Crustacea, Brachyura, Ocypodidae). Micron, New York, v. 39, n. 3, p. 337-343, 2008.

BEZERRA, L. E. A.; MATTHEWS-CASCON, H. Population structure of the fiddler crab Uca leptodactyla Rathbun 1898 (Brachyura: Ocypodidae) in a tropical mangrove of northeast Brazil. Thalassas, Santiago de Compostela, v. 22, p. 65-74, 2006.

BEZERRA L. E. A.; MATTHEWS-CASCON, H. Population and reproductive biology of the fiddler crab Uca thayeri (Crustacea: Ocypodidae) in a tropical mangrove from Northeast Brazil. Acta Oecologica, Paris, v. 31, p. 251-258, 2007.

BRANCO, J. O.; BRANCO, M. J. L.; AVILA, M. G.; MIGUEZ, C. F. Interação entre fator de condição e índice gonadossomático como indicadores do período de desova em Callinectes danae Smith (Crustacea, Portunidae) da Lagoa da Conceição, Florianópolis, Santa Catarina, Brasil. Revista Brasileira de Zoologia, Curitiba, v. 9, n. 3/4, p. 175-180, 1992.

BRANCO, J. O.; THIVES, A. Relação peso, fator de condição e tamanho da primeira maturação de Callinectes danae Smith, 1869 (Crustacea, Portunidae) no manguezal do Itacoribi, SC, Brasil. Arquivos de Biologia e Tecnologia, Curitiba, v. 34, n. 3/4, p. 415424, 1991.

CARDOSO, F. C. R.; NEGREIROS-FRANSOZO, M. L. A comparison of the allometric growth in Uca leptodactyla (Crustacea: Brachyura: Ocypodidae) from two subtropical estuaries. Journal of the Marine Biology Association of the United Kingdom, London, v. 84, p. 733-735, 2004.

CASTIGLIONI, D. S.; NEGREIROS-FRANSOZO, M. L. Somatic growth of the mudflat fiddler crab Uca rapax (Smith, 1870) (Brachyura, Ocypodidae) from two subtropical mangroves in Brazil. Universidad y Ciencia, Tabasco, v. 20, n. 39, p. 15-22, 2004.

CASTIGLIONI, D. S.; NEGREIROS-FRANSOZO, M. L.; MORTARI, R. C. Biologia populacional do caranguejo violinista Uca rapax (Smith, 1870) (Crustacea, Ocypodoidea), proveniente de uma área de manguezal degradado em Paraty, RJ, Brasil. Atlântica, Rio Grande, v. 28, n. 2, p. 73-78, 2006.

CEPRO - FUNDAÇÃO CENTRO DE PESQUISAS ECONÔMICAS E SOCIAIS DO PIAUÍ. Diagnóstico do município de Parnaíba. 2013. Disponível em: <http://www.cepro. pi.gov.br/download/201309/CEPRO27_61e146ba45.pdf>. Acesso em: 2 jan. 2015.
CHRISTY, J. H.; SALMON, M. Ecology and evolution of mating systems of fiddler crabs (Genus Uca). Biological Reviews, Cambridge, v. 59, p. 483-509, 1984.

COBO, V. J.; FRANSOZO, A. Relative growth of Goniopsis cruentata (Crustacea, Brachyura, Grapsidae), on the Ubatuba region, São Paulo, Brazil. Iheringia, Série Zoologia, Porto Alegre, v. 84, p. $21-28,1998$.

COLPO, K. D.; NEGREIROS-FRANSOZO, M. L. Comparison of the population structure of the fiddler crab Uca vocator (Herbst, 1804) from three subtropical mangrove forests. Scientia Marina, Barcelona, v. 68, n. 1, p. 139-146, 2004.

DI BENEDETTO, M.; MASUNARI, S. Estrutura populacional de Uca maracoani (Decapoda, Brachyura, Ocypodidae) no Baixio Mirim, Baía de Guraratuba, Paraná. Iheringia, Série Zoologia, Porto Alegre, v. 99, p. 381-389, 2009.

DÍAZ, H.; CONDE, J. E. Population dynamics and life of mangrove crab Aratus pisonii (Brachyura, Grapsidae) in a marine environment. Bulletin of Marine Science, Miami, v. 45, p. 148$163,1989$.

FONTELES-FILHO, A. A. Oceanografia, biologia e dinâmica populacional de recursos pesqueiros. Fortaleza: Expressão Gráfica e Editora, 2011. 464 p.

FRANSOZO V. C.; MORTARI, R. C.; BENETTI, A. S. Population biology of Uca mordax (Smith, 1870) (Crustacea, Decapoda, Ocypodidae) from the southeastern coast of Brazil. Estudos de Biologia, Curitiba, v. 31, p. 23-31, 2009.

GÓES, J. M.; FRANSOZO, A. Relative growth of Eriphia gonagra (Fabricius, 1781) (Crustacea, Decapoda, Xanthidae) in Ubatuba, State of São Paulo, Brazil. Nauplius, Porto Alegre, v. 5, n. 2, p. 85-98, 1997.

HARTNOLL, R. G. Growth. In: ABELE, L. G. (Ed.). The biology of Crustacea. Vol. 2. New York: Academic Press, 1982. p. 111-196.

JOHNSON, P. T. J. Biased sex ratios in fiddler crabs (Brachyura, Ocypodidae): a review and evaluation of the influence of sampling method, size class and sex-specific mortality. Crustaceana, Leiden, v. 76, p. 559-580, 2003.

LITULO, C. Population biology of the fiddler crab Uca annulipes (Brachyura: Ocypodidae) in a tropical East African Mangrove (Mozambique). Estuarine, Coastal and Shelf Science, New York, v. 62, p. 283-290, 2005a.

LITULO, C. Population structure and reproductive biology of the fiddler crab Uca inversa (Hoffman, 1874) (Brachyura: Ocypodidae). Acta Oecologica, Paris, v. 27, p. 135-141, 2005 b.

MANTELATTO, F. L. M.; FRANSOZO, A. Crescimento relativo e dimorfismo sexual em Hepatus pudibundus (Herbst, 1785) (Decapoda, Brachyura) no litoral norte paulista. Papéis Avulsos de Zoologia, São Paulo, v. 39, n. 4, p. 33-48, 1994.

MARCELINO, A. M. T.; OLIVEIRA, J. E. L.; LEITE, T. S.; CASTRO, P. T.; ARARIPE, H. G. A. Caracterização dos ecossistemas costeiros dos estados do Rio Grande do Norte. Brasília: Ministério do Meio Ambiente, 2002, 70 p.

MASUNARI, S.; DISSENHA, N. Alometria no crescimento de Uca mordax (Smith) (Crustacea, Decapoda, Ocypodidae) na Baía de Guaratuba, Paraná, Brasil. Revista Brasileira de Zoologia, Curitiba, v. 22, n. 4, p. 984-990, 2005. 
MASUNARI, S.; DISSENHA, N.; FALCÃO, R. C. Crescimento relativo e destreza dos quelípodos em Uca maracoani (Crustacea, Decapoda, Ocypodidae) no Baixo Mirím, Baía de Guaratuba, Paraná, Brasil. Revista Brasileira de Zoologia, Curitiba, v. 22, n. 4, p. 974-983, 2005.

MASUNARI, S.; SWIECH-AYOUB, B. P. Crescimento relativo em Uca leptodactyla Rathbun (Crustacea, Decapoda, Ocypodidae). Revista Brasileira de Zoologia, Curitiba, v. 20, n. 3, p. 487-491, 2003.

MOKHLESI, A.; KAMRANI, E.; BACKWELL, P. R. Y.; SAJJADI, M. Study on the behaviour of two fiddler crabs, Uca sindensis and Uca annulipes (Decapoda: Ocypodidae) in Bandar Abas, Iran. Journal of the Marine Biology Association, Cambridge, v. 91, n. 1, p. 245-249, 2010.

MOKHTARI, M.; SAVARI, A.; REZAI, H.; KOCHANIAN, P.; BITAAB, A. Population ecology of fiddler crab, Uca lactea annulipes (Decapoda, Ocypodidae) in Sirik mangrove estuary, Iran. Estuarine, Coastal and Shelf Science, New York, v. 76, p. 273281, 2008.

PEZZUTO, P. R. REGRANS: a "basic" program for an extensive analysis of relative growth. Atlântica, Rio Grande, v. 15, p. 93-105, 1993.

PINHEIRO, M. A. A.; TADDEI, F. G. Relação peso/tamanho e fator de condição em Dilocarcinus pagei Stimpson, 1861 (Crustacea, Brachyura, Trichodactylidae). Revista Brasileira de Zoologia, Curitiba, v. 22, n. 4, p. 825-829, 2005.

PRALON, B. G. N.; NEGREIROS-FRANSOZO, M. L. Relative growth and morphological sexual maturity of Uca cumulanta (Crustacea, Decapoda, Ocypodidae) from a tropical Brazilian mangrove population. Journal of the Marine Biological Association of the United Kingdom, Cambridge, v. 88, p. 569574, 2008.
RIEGER, P. J. Desenvolvimento larval de Uca (Minuca) burgersi Holthuis (Crustacea, Decapoda, Ocypodidae), em laboratório. Revista Brasileira de Zoologia, Curitiba, v. 15, n. 3, p. 727-756, 1998.

ROSENBERG, M. S. Fiddler crab claw shape variation: a geometric morphometric analysis across the genus Uca (Crustacea: Brachyura: Ocypodidae). Biological Journal of the Linnean Society, London, v. 75, p. 147-162, 2002.

SANTOS, E. P. Dinâmica de populações aplicada à pesca e piscicultura. São Paulo: Hucitec, EDUSP. 1978. 129 p.

SANTOS, S.; FRANSOZO, M. L. N.; PADOVANI, C. R. Relação do peso do corpo em função da largura da carapaça do siri candeias Portunus spinimanus Latreille, 1819 (Crustacea, Decapoda). Arquivos de Biologia e Tecnologia, Curitiba, v. 38, n. 3, p. 715 724, 1995.

SIMITH, B. D. D. J.; PIRES, M. A. B.; ABRUNHOSA, F. A.; MACIEL, C. R.; DIELE, K. Is larval dispersal a necessity for decapod crabs from the Amazon mangroves? Response of $U c a$ rapax zoeae to different salinities and comparison with sympatric species. Journal of Experimental Marine Biology and Ecology, Amsterdam, v. 457, p. 22-30, 2014.

WEIS, J.; WEIS, P. Behavior of four species of fiddler crabs, genus $U c a$, in Southeast Sulawesi, Indonesia. Hydrobiologia, Brussels, v. 523, n. 1/3, p. 47-58, 2004.

ZAR, J. H. Biostatistical analysis. 5. ed. Upper Saddle River: Pearson Prentice-Hall, 2010. 944 p. 